Article

\title{
Intrinsic Motivation Sources as Pillars of Sustainable Internal Marketing Communication in Turbulent Post-Pandemic Times
}

\author{
Jana Majerova ${ }^{1, *}$, Lubica Gajanova ${ }^{2}$ D, Margareta Nadanyiova ${ }^{2}$ (D) and Anita Kolnhofer Derecskei ${ }^{3,4}$ \\ 1 Department of Economics and Management, AMBIS University, Lindnerova 575/1, \\ 18000 Prague, Czech Republic \\ 2 Department of Economics, Faculty of Operation and Economics of Transport and Communications, \\ University of Zilina, Univerzitna 1, 01026 Zilina, Slovakia; lubica.gajanova@fpedas.uniza.sk (L.G.); \\ margareta.nadanyiova@fpedas.uniza.sk (M.N.) \\ 3 Faculty of Business and Economics, University of Melbourne, Melbourne 3010, Australia; \\ derecskei.anita@kgk.uni-obuda.hu \\ 4 Keleti Károly Faculty of Business and Management, Obuda University, H-1084 Budapest, Hungary \\ * Correspondence: jana.majerova@ambis.cz; Tel.: +421-904-391-272
}

\section{check for} updates

Citation: Majerova, J.; Gajanova, L.; Nadanyiova, M.; Kolnhofer Derecskei, A. Intrinsic Motivation Sources as Pillars of Sustainable Internal Marketing Communication in Turbulent Post-Pandemic Times. Sustainability 2021, 13, 8799. https:// doi.org/10.3390/su13168799

Academic Editors: Grigorios

L. Kyriakopoulos, Lenka Ližbetinová, Eva Nedeliaková and Miloš Hitka

Received: 23 April 2021

Accepted: 3 August 2021

Published: 6 August 2021

Publisher's Note: MDPI stays neutral with regard to jurisdictional claims in published maps and institutional affiliations.

Copyright: (c) 2021 by the authors Licensee MDPI, Basel, Switzerland. This article is an open access article distributed under the terms and conditions of the Creative Commons Attribution (CC BY) license (https:/ / creativecommons.org/licenses/by/ $4.0 /)$.

\begin{abstract}
The main aim of the article is to identify the changes in employees' sources of intrinsic motivation caused by the impact of the COVID-19 pandemic, and to discuss prospective modifications to formulated patterns of internal marketing communication. The novelty of the research lies in two main aspects: (1) the necessity to revise the traditional concept of motivation caused by the pandemic and (2) own methodological approach. While the first aspect reflects the lack of appropriate scientific attention paid to this issue, the second aspect develops methodological approaches applied so far in the research of intrinsic motivation sources. The goal of the paper has been achieved via own questionnaire research of the traditional quadratic structure of the intrinsic motivation sources of employees. The data from socio-demographically representative sample of 2000 respondents have been in accordance with contemporary trends in managerial analytics analysed via factor analysis and relevant statistic tests. It has been found that the ranking of intrinsic motivation sources before the COVID-19 pandemic was the following: (1) sense of choice; (2) sense of meaningfulness; (3) sense of progress and (4) sense of competence. The ranking of intrinsic motivation sources during the COVID-19 pandemic was the following: (1) sense of choice; (2) sense of progress; (3) sense of meaningfulness; and (4) sense of competence. Based on the identified changes in intrinsic motivation sources and their components, it can be stated that the pandemic has significantly influenced the existing principles and patterns of internal marketing communication. These should be critically reconsidered, and motivation systems should be revised to contribute to the optimal performance of the company on the market and its sustainable development by focusing on the financial situation of the company, significant for the economic pillar; the change in individual value scales, significant for the environmental pillar; and the phenomenon of millennials, significant for the social pillar. By intersecting these pillars, sustainability can be reached based on finding optimum motivation.
\end{abstract}

Keywords: intrinsic motivation; extrinsic motivation; financial situation; millennials; sustainable internal communication; sustainability; COVID-19

\section{Introduction}

The black swan, in the form of the COVID-19 pandemic, has flown over us, and traditional social stereotypes have changed radically. Managerial theory necessitates the reflection in the managerial practice of the changes taking place in the individual value scales. While there are some areas when this need is not so urgent and the shift in trends is rather slow, there are many more areas where the shift in trends is radical. Personal management and internal marketing communication are the areas where the black swan effect is the most obvious. However, there is not only the aspect of flexibly reflecting 
actual trends in the managerial patterns. Another, even more important aspect, lies in the stabile character of this phenomenon. It is because apart from the current pandemic reality, there is also the post-pandemic expectation of a turbulent market and managerial reality. Despite the fact that the black swan theory was discussed in the wider socio-economic prospective by Taleb at the very beginning of 21st century, there has not been sufficient scientific interest paid to this topic so far [1-4]. According to Parameswar et al., who have provided the bibliometric analysis of research agenda of the black swan, the search for articles only yielded 59 articles up to the end of year 2020 where they identified three basic levels of the black swan effect study: pre-black swan, black swan and post-black swan [5]. However, these levels are not discussed in comparable range. The main scientific interest is concentrated in the black swan effect in crises [6]. The pre- and post- phases are discussed only marginally. This paper aims to fulfil this scientific gap. Only effective internal marketing communication can be considered a suitable platform for a sustainable competitive advantage based on appropriately motivated employees. Such effectiveness is challenging to find. However, the ambition of the collective of authors is to identify relevant contemporary sources of intrinsic motivation. The research question of the paper was therefore set out as follows: has there been a change in the sources of intrinsic motivation of employees in terms of reflecting the theory of the black swan in the form of the COVID-19 pandemic?

The paper consists of six sections. In the first one, brief introduction into the topic of intrinsic motivation sources, and the pandemic's impact on them, is provided. In the second one, current state of knowledge is realized via literature review where the basic theoretical platform for own research is summarized. Later, methodological part of the paper is included. In this part, data are described, as well as the process of their collection and the statistical apparatus, which is going to be applied to reach the objectives of the paper. The following part contains the results and the discussion where the findings of this research are critically compared with contemporary scientific postulates. Based on this comparison, the implications for the theory and managerial practice are formulated in the next part of the paper, where the limits of the research, as well as its future directions are also listed. The paper is finalized with the concluding part where the essence of the paper is highlighted.

\section{Literature Review}

While in the case of pre-black swan this fact is reasonable and lies in the pure nature of the black swan (unpredictability and suddenness), in the case of the post-black swan effect this situation is surprising [7]—-mainly because a significant effect of the black swan on further socio-economic development was proved [8]. Castles highlighted the need of research in this area just after the global economic crisis in 2010 [9]. Since then, no procedural approach to include post-black swan impacts on managerial theory and practice has been created. On the one hand, each black swan is characterized by its own specifics and socio-economic interactions [10]. On the other hand, the strategic competitive advantage lies in the timely identification of relevant changes and their implementation into internal processes of the company [11]. However, the attention of theory and practice is currently focused mainly on hot topics of dealing with the pandemic's black swan on an operative basis. Thus, for example Rind et al. analyze the issue of adjusting working conditions and evaluating the risk of infection during the COVID-19 pandemic in different workplace settings in Germany [12]. However, countries around the world have been handling the COVID-19 pandemic differently. Bhattacharyya and Tharke study strategic initiatives and tactical responses of firms on the coronavirus pandemic and economic lockdown [13]. Ebersberger and Kuckertz discuss the impact of organization type on innovation response time to the COVID-19 crisis [14]. As it is demonstrated, contemporary scientific activities within the scope of the pandemic's black swan are focused on actual issues of dealing with this socio-economic phenomenon. Neither is their fragmentation in favor of establishing prospective future competitive advantage [15]. In accordance with what was mentioned 
above, the main aim of the article is to identify changes in intrinsic motivation sources of employees caused by the impact of the COVID-19 pandemic, and to discuss prospective modifications to the already formulated patterns of internal marketing communication. Such a statement of the aim is reasoned by the following research presumptions:

(1) financial situation of many companies would not allow continuing in attractive extrinsic motivation programs;

(2) the pandemic has changed individual value scales in favor of non-material ones; and

(3) millennials and younger generations as strengthening generations on the job market are characterized by a hedonic life approach and preference of intrinsic motivation sources.

These three main research presumptions reflect the traditional pillars of corporate social responsibility - the financial situation for the economic pillar, the change in individual value scales for the environmental pillar and the phenomenon of millennials for the social pillar. Moreover, the concept of intrinsic motivation sources has a significant social character. By intersecting these pillars, sustainability can be reached.

Based on Vroom's theory of expectance, Lawler et al. proposed the concept of extrinsic and intrinsic work motivation [16]. Amabile and Kramer were the first pioneers who widely studied intrinsic and extrinsic motivation at workplaces. They have pointed out that managers are more powerful in scope of employees' non-financial motivation and optimal working output via focusing on actions that support working progress and distinguish them adequately from those that have the opposite effect. These prospective positive non-financial motivators were detected by them: (1) setting clear goals; (2) providing sufficient time and resources; and (3) offering recognition [17]. According to Cerasoli et al., thanks to intrinsic motivation, employees engage in activities because they find them interesting and because these activities bring them spontaneous satisfaction [18]. In contrast, extrinsic motivation requires a certain middle element-the means between activity and consequences, mainly in the form of material or verbal reward [19]. Thus, in the case of extrinsic motivation, satisfaction comes not as a consequence of the activity itself, but as a consequence of the extrinsic consequences that the activity leads to [20]. A typical example of extrinsic motivation is financial reward, and it acts as a more significant motivating factor, especially for manual jobs. However, this is not a general rule and individual characteristics of the profile of the employees on certain positions should be accepted when the motivation system is applied on them [21]. According to this fact, the work environment should be structured so that work performance leads to both extrinsic and intrinsic rewards, which would result in an individual's overall job satisfaction [22]. Contemporary scientific approaches to intrinsic motivation practically follow existing long-term theoretical flows [23]. Mardanov discusses the relationship between intrinsic and extrinsic motivation, organizational context, employee contentment, job satisfaction, performance and intention to stay [24]. Montani et al. analyze intrinsic motivation focusing on the job insecurity and innovative work behavior [25]. Similarly, other authors also elaborate more sophisticated reasoning of the identified attributes of intrinsic motivation [26-30]. However, a complex scientific view of the intrinsic motivation in post-pandemic restructuring of individual scale of values is still missing.

First, it can be expected that the financial situation of many companies would not allow the continuation of attractive extrinsic motivation programs. Current economic situation indicates financial problems of many companies, sectors and national economies [31]. Ellul et al. highlight the need of searching for possibilities to optimize expenditures across all managerial areas [32]. In addition, Acharya and Steffen recommend this as insolvency prevention [33]. Carletti et al. have indicated radical decline of profits, which would continue in post-pandemic times due to the phenomenon of increasing social poverty [34]. The slight continuing decline of stock prices stated by Ramelli and Wagner is an only logic consequence of this fact [35]. This is obvious not only in primarily affected sectors like tourism, hospitality and gastronomy but with time also in sectors that have originally been predicted to be protected against the impact of the pandemic [36]. This is how the impact 
of the COVID-19 pandemic on household finances discussed by Achou et al. significantly influences corporate wealth and the financial situation of companies [37]. Despite it being almost impossible to predict the overall impact of the pandemic on the global economy and society, according to Spatt, the wider prospective of the experience from the mortgage crisis in 2008 can be applied to extrapolate statistical data and to formulate relevant conclusions [38].

Similarly, it can be expected that the pandemic has changed individual value scales in favor of non-material ones. It is not only because purchasing behavior has changed [39]. Steinert has stated that the coronavirus crisis may contribute to overall societal value change [40]. However, a complex study of this social phenomenon is still missing despite the bigger statistic samples used [41]. This topic is mainly analyzed on two basic levels: (1) focusing on social groups and (2) focusing on the sectoral structure of national economies where these changes are visible [42]. In accordance with first prospective, Daniels et al. have identified that the impact of COVID-19 triggered changes to instruction and assessment of university students' self-reported motivation, engagement and perceptions [43]. Similarly, Sakib et al. provide a comparative study among the general population and healthcare professionals during the COVID-19 pandemic crisis in Bangladesh [44]. When the second level is discussed, the research interest is paid mainly to the most damaged sectors like tourism, hospitality, gastronomy, i.e. $[45,46]$. The mechanisms of social psychology are also expected to be slightly changed under the impact of the pandemic [47], as well as the quality and perception of emotions and their importance to the work-life balance concept [48].

Finally, it can be expected that millennials as a strengthening generation on the job market are characterized by a hedonic life approach and a preference of intrinsic motivation sources. Moreover, generational specifics is not the only significant phenomenon in the scope of prospective job market implications. According to International Labor Organization, the pandemic has changed the attitudes of the youth towards jobs, education, rights and mental well-being [49]. In general, baby boomers reported that person-organization values fit better with extrinsic values and status values than those of Generation $X$ or Generation Y [50]. It has also been stated that considering young adults (millennials), trust and its power as a social resource seem to be highly relevant for the future [51]. Other aspects that have been previously identified as relevant for transforming the job market in the light and shadow of the strengthening participation of Generation Y (millennials) are: (1) work engagement directly proportional to the meaningfulness of work [52]; (2) work well-being and comfort feelings [53]; and (3) emphasis on the freedom of thought and movement [54]. Thus, significant discrepancies among generation cohorts (not only the specifics of Generation $Y$ but also the overall generational diversity) are present in the job market in general [55]. According to Mahmoud et al., Generation Z is more sensitive to amotivation than Generation $X$ and Generation Y. Extrinsic regulation-material is a valid source of overall work motivation for Generation Z only. Only Generation X values extrinsic regulation-social as a source of employees' overall motivation. So, it is interjected regulation by Generation Y. Unlike Generation Z, both Generation X and Generation Y employees value identified regulation as a source of overall work motivation. Finally, intrinsic motivation contributes more to Generation $\mathrm{Z}$ employees' overall work motivation than it does for Generation X and Generation Y [56]. Similarly, Hashiguchi et al. recently analyzed the age-dependent influence of intrinsic and extrinsic motivations on construction worker performance finding out that both, younger and older workers were affected by intrinsic motivations and extrinsic motivations, but the effect of these motivations on work performance differed depending on age [57]. On the other hand, there are also aspects where generational differences are not significant. Surprisingly, these are relevant to individual intrinsic motivation sources. Brink and Zondag examine job attribute preferences across three generational cohorts, and they found out that organizations should pause before making wholesale changes to workplace incentives and practices to cater to the new generation [58]. According to Tuncbilek and Sucu, there is no relationship between job 
satisfaction and work stress factors when comparing Generation X and Y [59]. Gurbuz and Aytekin similarly found little evidence supporting substantive and significant generational differences or their association with key outcome variables [60]. However, this research has a framework structure. Thus, apart from the traditional quadratic structural scheme of intrinsic motivation sources, mainly the preference structure of individual internal components of these sources should be analyzed and discussed. Moreover, it is not enough to discuss Generation Y as a homogeneous group of employees, but their national psychographic specifics must be taken into account. Other characteristics of each generation are more specified by their life period [61]. According to Hitka et al., fundamental patterns of cultural differences, as well as age-related differences predicting motivational preferences can be taken into consideration when selecting optimal motivation factors [62,63]. In this prospective, specific status of Slovak Republic as a national psychographic environment has been proved [64]. Thus, we have focused in our own research on the population of Slovak employees who can be used as an optimal pilot sample to provide research in an international prospective. Subsequently, it would lead to creating not only locally effective but generally applicable managerial advice on how to base sustainable internal communication on relevant motivation sources in international working collectives [65].

\section{Materials and Methods}

To achieve the aim of the study, the data were collected via own research. The research was carried out in two phases, in the first quarter of 2020 (before COVID-19) and in the first quarter of 2021 (during COVID-19). The sample size was 2000 respondents older than 15 in the case of both phases of the survey. For such a large sample size, the distribution of the sample approximates a normal distribution, which can be proved by a central limit theorem [66]. An age restriction was formulated because of the legal system of the Slovak Republic, which acknowledges legal working subjectivity based on this age limit [67].

The demographic profiles of the samples are summarized in Table 1. Based on the number of frequencies, it can be concluded that the representation of individual traits is in the context of the entire population.

Table 1. Demographic characteristics of the samples.

\begin{tabular}{|c|c|c|c|c|}
\hline \multirow{2}{*}{$\begin{array}{c}\text { Demographic } \\
\text { Categories }\end{array}$} & \multicolumn{2}{|c|}{ Before COVID-19 } & \multicolumn{2}{|c|}{ During COVID-19 } \\
\hline & Frequency & Percentage & Frequency & Percentage \\
\hline \multicolumn{5}{|c|}{ Gender } \\
\hline Female & 1211 & 60.55 & 1108 & 55.40 \\
\hline Male & 789 & 39.45 & 892 & 44.60 \\
\hline \multicolumn{5}{|c|}{ Age } \\
\hline $\begin{array}{c}74-56 \\
\text { (Generation BB) }\end{array}$ & 331 & 16.55 & 308 & 15.40 \\
\hline $\begin{array}{c}55-40 \\
(\text { Generation X) }\end{array}$ & 651 & 32.55 & 614 & 30.70 \\
\hline $\begin{array}{c}\text { 39-24 } \\
(\text { Generation Y) }\end{array}$ & 685 & 34.25 & 727 & 36.35 \\
\hline $\begin{array}{c}23-15 \\
\text { (Generation Z) }\end{array}$ & 333 & 16.65 & 351 & 17.55 \\
\hline \multicolumn{5}{|c|}{ Educational attainment level } \\
\hline Primary & 157 & 7.85 & 188 & 9.40 \\
\hline Secondary & 1199 & 59.95 & 1103 & 55.15 \\
\hline Tertiary & 644 & 32.20 & 709 & 35.45 \\
\hline \multicolumn{5}{|c|}{ Length of current employment } \\
\hline less than 1 year & 119 & 5.95 & 139 & 6.95 \\
\hline $1-3$ years & 239 & 11.95 & 226 & 11.30 \\
\hline $4-5$ years & 644 & 32.20 & 583 & 29.15 \\
\hline
\end{tabular}


Table 1. Cont.

\begin{tabular}{|c|c|c|c|c|}
\hline \multirow{2}{*}{$\begin{array}{c}\text { Demographic } \\
\text { Categories }\end{array}$} & \multicolumn{2}{|c|}{ Before COVID-19 } & \multicolumn{2}{|c|}{ During COVID-19 } \\
\hline & Frequency & Percentage & Frequency & Percentage \\
\hline \multirow{2}{*}{$\begin{array}{c}5-7 \text { years } \\
\text { more than } 7 \\
\text { years }\end{array}$} & 566 & 28.30 & 617 & 30.85 \\
\hline & 432 & 21.60 & 435 & 21.75 \\
\hline \multicolumn{5}{|c|}{ Disposable income } \\
\hline$<10,000$ & 278 & 13.90 & 254 & 12.70 \\
\hline$<15,000$ & 466 & 23.30 & 421 & 21.5 \\
\hline$<20,000$ & 721 & 36.05 & 749 & 37.45 \\
\hline$<25,000$ & 336 & 16.80 & 355 & 17.75 \\
\hline$>25,000$ & 199 & 9.95 & 221 & 11.5 \\
\hline Total & 2000 & 100 & 2000 & 100 \\
\hline
\end{tabular}

Source: Authors' own research, 2021.

However, it has to be stated that one of the limitations of general applicability of the research outcomes lies in this fact. That is, the applicability and implementation of the recommendations done on the basis of research outcomes is justified only in the scope of Slovak employee's preferences. The questionnaire has been composed of two parts: (1) socio-demographic profile of respondents and (2) employees' individual intrinsic motivation sources. To provide research of intrinsic motivation sources of employees, traditional quadratic typology of its composition has been chosen. In scope of this theory, these are the main intrinsic motivation sources: (1) sense of meaningfulness; (2) sense of choice; (3) sense of competence; and (4) sense of progress. These intrinsic motivation sources and their components are summarized in Table 2. Respondents were asked to what extent they would be affected by each component of intrinsic motivation during work performance. They were able to express their attitude using a 5-point scale, where 1 was very strong influence and 5 was very weak influence. To identify the changes in intrinsic motivation sources of employees, caused by the impact of the COVID-19 pandemic, matched pair experimental design was used where each observation (before COVID-19) from the first sample can be matched with the second (during COVID-19) observation in another sample.

The intrinsic motivation sources of employees before COVID-19 pandemic and during COVID-19 pandemic have been in accordance with contemporary trends in managerial analytics analyzed via factor analysis. Factor analysis is a statistical method that explains or describes the variance of measured, manifest variables [68]. This is done with the help of a smaller number of latent, constructed, unobserved variables, i.e., factors. Factor analysis, based on correlations between a quantity of (measured, manifest) variables, statistically determines whether some variables belong to each other, i.e., whether one common factor (latent variable) binds them or whether they belong to another common factor. Therefore, the main goal of factor analysis based on the dependencies of the observed variables is to know and use the structure of directly unobservable common factors [69]. The aim is to find common factors (defined as a linear combination of the original quantities) so that they can best and easily explain the observed dependencies. In the final solution, therefore, each variable should correlate with the minimum number of factors and at the same time the number of factors should be as small as possible, but at the same time it must correspond to the actual size of the task and data. This method is used more often in the social sciences to reduce subjectivity in the analysis of large amounts of data obtained due to technological development [70]. 
Table 2. Components of intrinsic motivation sources.

\begin{tabular}{cc}
\hline $\begin{array}{c}\text { Intrinsic Motivation } \\
\text { Sources }\end{array}$ & Components of Intrinsic Motivation Sources \\
\hline sense of meaningfulness & $\begin{array}{c}\text { a non-cynical climate (freedom to care deeply) } \\
\text { clearly identified passions (insight into what we care about) } \\
\text { an exciting vision (a vivid picture of what can be accomplished) } \\
\text { relevant task purposes (connection between our } \\
\text { work and the vision) } \\
\text { whole tasks (responsibility for an identifiable product or service) } \\
\text { delegated authority (the right to make decisions) } \\
\text { trust (confidence in an individual's self-management) } \\
\text { security (no fear of punishment for honest mistakes) } \\
\text { a clear purpose (understanding what we are trying to accomplish) } \\
\text { information (access to relevant facts and sources) }\end{array}$ \\
knowledge (an adequate store of insights \\
from education and experience) \\
fense of competence \\
positive feedback (information on what is working) \\
skill recognition (due credit for our successes) \\
challenge (demanding tasks that fit our abilities) \\
non-comparative standards (demanding standards that \\
don't force rankings)
\end{tabular}

Source: Authors' own research, 2021.

The starting point of the factor analysis is the correlation matrix, i.e., the inter correlation between all the measured variables [71]. The result is a factor matrix (list of specified factors), which is empirically defined by the so-called factor loads (correlations with initial variables). Factor analysis is based on a linear model, i.e., on the assumption that all examined variables are linear combinations of factors. Then Equation (1) applies to a typical object researched:

$$
z_{i j}=a_{j 1} F_{1 i}+a_{j 2} F_{2 i}+a_{j 3} F_{3 i}+\ldots
$$

where $z_{j i}$ is individual score (value) of the variable, $z_{j}, a_{j 1}, a_{j 2}, \ldots$ are factor loadings of the individual factors of the respective variable and $F_{1 i}, F_{2 i}, \ldots$ are factor score of an individual (object). The individual correlations between the variables are then given by the equation:

$$
r_{j k}=a_{j 1} a_{k 1}+a_{j 2} a_{k 2}+a_{j 3} a_{k 3}+\ldots
$$

The first stage of the whole procedure depends on the extraction of factors, i.e., the determination of the smallest possible number of factors, which can explain all correlations between variables and from which it is possible according to Equation (2) to reproduce the correlation matrix. This achieves maximum economy in the description of the investigated objects, which have so far been characterized by a larger, less clear number of variables. Since the extracted factors are largely arbitrary, the rotation of the factors is further executed. A simple structure is achieved when each variable is described by the smallest possible number of determined factors, i.e., when in Equation (1) there are as many values as possible (factor loads) close to zero. Rotation often results in correlated factors. The last stage of factor analysis is the interpretation of specified factors based on factor loads. The factor is usually interpreted according to the content of variables to which it has the closest relationship according to its highest loads. The determined factors often coincide with already known terms. Their content and scope are then only specified and confirmed 
by factor analysis. The initial conditions of factor analysis include (a) high correlations of a large number of variables and (b) low partial correlations. Whether the correlation and partial correlation matrices satisfy the assumptions is therefore tested by various coefficients and indices, usually Kaiser-Meyer-Olkin measure (KMO) and Bartlett's test of sphericity. The KMO measure is based on the principle that if variables share common factors, then partial correlations between pairs of variables should be small when the effects of other variables are controlled. The KMO measure provides an approach to comparing the zero-order correlations to the partial correlations [72]. High KMO values (close to 1, at least 0.6$)$ and the significance of the Bartlett test $(p<0.001)$ indicate that the mentioned initial assumptions of factor analysis are statistically sufficient [73]. Kaiser-Meyer-Olkin measure is the measure of the adequacy of the selection, and it is given by Equation (3):

$$
K M O=\frac{\sum_{j \neq j \prime}^{p} \sum_{j \neq j \prime}^{p} r^{2}\left(x_{j}, x_{j \prime}\right)}{\sum_{j \neq j \prime}^{p} \sum_{j \neq j \prime}^{p} r^{2}\left(x_{j}, x_{j \prime}\right)+\sum_{j \neq j \prime}^{p} \sum_{j \neq j \prime}^{p} r^{2}\left(x_{j}, x_{j \prime} . \text { other } x\right)}
$$

where $r^{2}\left(x_{j}, x_{j^{\prime}}\right)$ are simple correlation coefficients and $r^{2}\left(x_{j}, x_{j^{\prime}}\right.$. other $\left.x\right)$ are partial correlation coefficients under the condition of statically constant remaining $\mathrm{p}-2$ variables. $\left(x_{1}, x_{2}, \ldots, x_{j-1}, x_{j+1}, \ldots, x_{j^{\prime}-1}, x_{j^{\prime}+1}, x_{p}\right)$. Bartlett test of sphericity is designed to verify the hypothesis of equal variances for normal distributions. The Bartlett test is given by the equation:

$$
T=\frac{(N-k) \ln s_{p}^{2}-\sum_{i=1}^{k}\left(N_{i}-1\right) \ln s_{i}^{2}}{1+\left(\frac{1}{3(k-1)}\right)\left(\left(\sum_{i=1}^{k} 1 /\left(N_{i}-1\right)\right)-1 /(N-k)\right)}
$$

where $s_{i}^{2}$ is the variance of the $i$ th group, $N$ is the total sample size, $N_{i}$ is the sample size of the $i$ th group, $k$ is the number of groups, and $s_{p}^{2}$ is the pooled variance. The pooled variance is a weighted average of the group variances and is defined as:

$$
s_{p}^{2}=\sum_{i=1}^{k}\left(N_{i}-1\right) / s_{i}^{2}(N-k)
$$

Based on these statistics tests, relevant basis for the reordering of intrinsic motivation sources of employees and their components before COVID-19 pandemic crisis and during COVID-19 pandemic crisis has been created. Therefore, managerial implications for optimal internal marketing communication in turbulent post-pandemic times can be formulated and patterns that have been created so far can be modified to take the reorganization of personal values ranking of employees into account.

\section{Results and Discussion}

The initial conditions of factor analysis were met. In both cases, the KMO test confirmed that the relationships between the two variables are real, close and not only mediated by the influence of the third variable in research issues. When testing the intrinsic motivation sources before COVID-19, the value of 0.912 was reached, and in the case of intrinsic motivation sources during COVID-19, the value of 0.920 was reached. Bartlett test has proved that not only is there self-correlation between the variables, but also dependencies between the variables with equal variances for normal distributions. The resulting value was 0.00 in case intrinsic motivation sources before COVID-19, as well as in case intrinsic motivation sources during COVID-19. The testimonial value of factor analysis of the intrinsic motivation sources before COVID-19 has reached a value of $67.445 \%$ (See Table 3). There are four components, which achieved Eigenvalues greater than 1 . The first component represents $41.377 \%$, the second one constitutes $10.904 \%$, the third one amounts to $8.846 \%$ and the last one represents $6.317 \%$ of the total variance. 
Table 3. Total variance explained-before COVID-19.

\begin{tabular}{|c|c|c|c|c|c|c|c|c|c|}
\hline \multirow{2}{*}{ Comp. } & \multicolumn{3}{|c|}{ Initial Eigenvalues } & \multicolumn{3}{|c|}{$\begin{array}{l}\text { Extraction Sum of } \\
\text { Squared Loadings }\end{array}$} & \multicolumn{3}{|c|}{$\begin{array}{l}\text { Rotation Sums of } \\
\text { Squared Loadings }\end{array}$} \\
\hline & Total & $\begin{array}{c}\text { \% of } \\
\text { Variance }\end{array}$ & $\begin{array}{c}\text { Cumulative } \\
\%\end{array}$ & Total & $\begin{array}{c}\text { \% of } \\
\text { Variance }\end{array}$ & $\begin{array}{c}\text { Cumulative } \\
\%\end{array}$ & Total & $\begin{array}{c}\% \text { of } \\
\text { Variance }\end{array}$ & $\begin{array}{c}\text { Cumulative } \\
\%\end{array}$ \\
\hline 1 & 8.275 & 41.377 & 41.377 & 8.275 & 41.377 & 41.377 & 3.792 & 18.962 & 18.962 \\
\hline 2 & 2.181 & 10.904 & 52.281 & 2.181 & 10.904 & 52.281 & 3.345 & 16.724 & 35.686 \\
\hline 3 & 1.769 & 8.846 & 61.127 & 1.769 & 8.846 & 61.127 & 3.187 & 15.935 & 51.621 \\
\hline 4 & 1.263 & 6.317 & 67.445 & 1.263 & 6.317 & 67.445 & 3.165 & 15.824 & 67.445 \\
\hline 5 & 0.956 & 4.781 & 72.226 & & & & & & \\
\hline 6 & 0.635 & 3.177 & 75.402 & & & & & & \\
\hline 7 & 0.550 & 2.752 & 78.155 & & & & & & \\
\hline 8 & 0.506 & 2.528 & 80.682 & & & & & & \\
\hline 9 & 0.463 & 2.313 & 82.995 & & & & & & \\
\hline 10 & 0.432 & 2.162 & 85.157 & & & & & & \\
\hline 11 & 0.415 & 2.076 & 87.233 & & & & & & \\
\hline 12 & 0.370 & 1.850 & 89.083 & & & & & & \\
\hline 13 & 0.356 & 1.781 & 90.865 & & & & & & \\
\hline 14 & 0.346 & 1.732 & 92.596 & & & & & & \\
\hline 15 & 0.335 & 1.675 & 94.271 & & & & & & \\
\hline 16 & 0.321 & 1.607 & 95.878 & & & & & & \\
\hline 17 & 0.289 & 1.444 & 97.322 & & & & & & \\
\hline 18 & 0.271 & 1.355 & 98.677 & & & & & & \\
\hline 19 & 0.253 & 1.265 & 99.941 & & & & & & \\
\hline 20 & 0.012 & 0.059 & 100 & & & & & & \\
\hline
\end{tabular}

Source: Authors' own research, 2021.

To improve the interpretation of the factors, a matrix was constructed using orthogonal rotation of Varimax (See Table 4). The results show the order of importance of intrinsic motivation sources by respondents in the time before COVID-19.

Table 4. Rotated component matrix-before COVID-19.

\begin{tabular}{|c|c|c|c|c|}
\hline \multirow{2}{*}{ Intrinsic Motivation Sources } & \multicolumn{4}{|c|}{ Components } \\
\hline & 1 & 2 & 3 & 4 \\
\hline a non-cynical climate (freedom to care deeply) & & 0.571 & & \\
\hline clearly identified passions (insight into what we care about) & & 0.761 & & \\
\hline an exciting vision (a vivid picture of what can be accomplished) & & 0.770 & & \\
\hline relevant task purposes (connection between our work and the vision) & & 0.743 & & \\
\hline whole tasks (responsibility for an identifiable product or service) & & 0.711 & & \\
\hline delegated authority (the right to make decisions) & 0.794 & & & \\
\hline trust (confidence in an individual's self-management) & 0.784 & & & \\
\hline security (no fear of punishment for honest mistakes) & 0.719 & & & \\
\hline a clear purpose (understanding what we are trying to accomplish) & 0.790 & & & \\
\hline information (access to relevant facts and sources) & 0.789 & & & \\
\hline knowledge (an adequate store of insights from education and experience) & & & & 0.807 \\
\hline positive feedback (information on what is working) & & & & 0.748 \\
\hline skill recognition (due credit for our successes) & & & & 0.508 \\
\hline challenge (demanding tasks that fit our abilities) & & & & 0.787 \\
\hline high, non-comparative standards (demanding standards that don't force rankings) & & & & 0.724 \\
\hline a collaborative climate (co-workers helping each other succeed) & & & 0.626 & \\
\hline milestones (reference points to mark stages of accomplishment) & & & 0.799 & \\
\hline celebrations (occasions to share enjoyment of milestones) & & & 0.824 & \\
\hline access to customers (interactions with those who use what we've produced) & & & 0.702 & \\
\hline measurement of improvement (a way to see if performance gets better) & & & 0.621 & \\
\hline
\end{tabular}


The determined factors coincide with traditional quadratic typology of intrinsic motivation sources of employees in this case. According to rotated component matrix it is also possible to rank the priority of employee's intrinsic motivation sources in the time before COVID-19 as follows:

1. Sense of choice;

2. Sense of meaningfulness;

3. Sense of progress;

4. Sense of competence.

This ranking together with the reliability as a result of an internal consistency of items by Cronbach's alpha is shown in Table 5.

Table 5. Intrinsic motivation sources-before COVID-19.

\begin{tabular}{ccccc}
\hline \multirow{2}{*}{ Factors } & F1 & F2 & F3 & F4 \\
\cline { 2 - 5 } & Sense of Choice & $\begin{array}{c}\text { Sense of Mean- } \\
\text { ingfulness }\end{array}$ & $\begin{array}{c}\text { Sense of } \\
\text { Progress }\end{array}$ & $\begin{array}{c}\text { Sense of } \\
\text { Competence }\end{array}$ \\
\hline N of Items & 5 & 5 & 5 & 5 \\
Cronbach's & 0.903 & 0.849 & 0.870 & 0.836 \\
$\begin{array}{c}\text { Alpha } \\
\text { \% of Variance }\end{array}$ & 41.377 & 10.904 & 8.846 & 6.317 \\
\hline
\end{tabular}

Source: Authors' own research, 2021.

The testimonial value of factor analysis of the intrinsic motivation sources during COVID-19 has reached a value of $65.853 \%$ (See Table 6). There are four components, which achieved Eigenvalues greater than 1 . The first component represents $40.902 \%$, the second one constitutes $10.506 \%$, the third one amounts to $8.170 \%$ and the last one represents $6.275 \%$ of the total variance.

Table 6. Total variance explained—during COVID-19.

\begin{tabular}{|c|c|c|c|c|c|c|c|c|c|}
\hline \multirow[b]{2}{*}{ Comp. } & \multicolumn{3}{|c|}{ Initial Eigenvalues } & \multicolumn{3}{|c|}{$\begin{array}{c}\text { Extraction Sums of Squared } \\
\text { Loadings }\end{array}$} & \multicolumn{3}{|c|}{$\begin{array}{c}\text { Rotation Sums of Squared } \\
\text { Loadings }\end{array}$} \\
\hline & Total & $\begin{array}{c}\% \text { of } \\
\text { Variance }\end{array}$ & $\underset{\%}{\text { Cumulative }}$ & Total & $\begin{array}{c}\% \text { of } \\
\text { Variance }\end{array}$ & $\begin{array}{c}\text { Cumulative } \\
\%\end{array}$ & Total & $\begin{array}{c}\% \text { of } \\
\text { Variance }\end{array}$ & $\begin{array}{c}\text { Cumulative } \\
\%\end{array}$ \\
\hline 1 & 8.180 & 40.902 & 40.902 & 8.18 & 40.902 & 40.902 & 3.629 & 18.145 & 18.145 \\
\hline 2 & 2.101 & 10.506 & 51.408 & 2.101 & 10.506 & 51.408 & 3.247 & 16.234 & 34.379 \\
\hline 3 & 1.634 & 8.170 & 59.578 & 1.634 & 8.170 & 59.578 & 3.160 & 15.802 & 50.181 \\
\hline 4 & 1.255 & 6.275 & 65.853 & 1.255 & 6.275 & 65.853 & 3.135 & 15.673 & 65.853 \\
\hline 5 & 0.952 & 4.758 & 70.611 & & & & & & \\
\hline 6 & 0.663 & 3.314 & 73.925 & & & & & & \\
\hline 7 & 0.543 & 2.716 & 76.641 & & & & & & \\
\hline 8 & 0.501 & 2.504 & 79.145 & & & & & & \\
\hline 9 & 0.472 & 2.361 & 81.505 & & & & & & \\
\hline 10 & 0.445 & 2.226 & 83.731 & & & & & & \\
\hline 11 & 0.438 & 2.190 & 85.921 & & & & & & \\
\hline 12 & 0.410 & 2.051 & 87.972 & & & & & & \\
\hline 13 & 0.376 & 1.881 & 89.853 & & & & & & \\
\hline 14 & 0.367 & 1.833 & 91.686 & & & & & & \\
\hline 15 & 0.351 & 1.753 & 93.440 & & & & & & \\
\hline 16 & 0.327 & 1.634 & 95.074 & & & & & & \\
\hline 17 & 0.305 & 1.527 & 96.601 & & & & & & \\
\hline 18 & 0.299 & 1.495 & 98.096 & & & & & & \\
\hline 19 & 0.276 & 1.380 & 99.476 & & & & & & \\
\hline 20 & 0.105 & 0.524 & 100 & & & & & & \\
\hline
\end{tabular}


To improve the interpretation of the factors, a matrix was constructed using orthogonal rotation of Varimax (See Table 7). The results show the order of importance of intrinsic motivation sources by respondents in the time during COVID-19.

Table 7. Rotated component matrix-during COVID-19.

\begin{tabular}{|c|c|c|c|c|}
\hline \multirow{2}{*}{ Intrinsic Motivation Sources } & \multicolumn{4}{|c|}{ Components } \\
\hline & 1 & 2 & 3 & 4 \\
\hline a non-cynical climate (freedom to care deeply) & & & 0.596 & \\
\hline clearly identified passions (insight into what we care about) & & & 0.744 & \\
\hline an exciting vision (a vivid picture of what can be accomplished) & & & 0.767 & \\
\hline relevant task purposes (connection between our work and the vision) & & & 0.752 & \\
\hline whole tasks (responsibility for an identifiable product or service) & & & 0.705 & \\
\hline delegated authority (the right to make decisions) & 0.740 & & & \\
\hline trust (confidence in an individual's self-management) & 0.779 & & & \\
\hline security (no fear of punishment for honest mistakes) & 0.744 & & & \\
\hline a clear purpose (understanding what we are trying to accomplish) & 0.802 & & & \\
\hline information (access to relevant facts and sources) & 0.786 & & & \\
\hline knowledge (an adequate store of insights from education and experience) & & & & 0.804 \\
\hline positive feedback (information on what is working) & & & & 0.757 \\
\hline skill recognition (due credit for our successes) & & & & 0.599 \\
\hline challenge (demanding tasks that fit our abilities) & & & & 0.794 \\
\hline high, non-comparative standards (demanding standards that don't force rankings) & & & & 0.623 \\
\hline a collaborative climate (co-workers helping each other succeed) & & 0.660 & & \\
\hline milestones (reference points to mark stages of accomplishment) & & 0.790 & & \\
\hline celebrations (occasions to share enjoyment of milestones) & & 0.820 & & \\
\hline access to customers (interactions with those who use what we've produced) & & 0.710 & & \\
\hline measurement of improvement (a way to see if performance gets better) & & 0.677 & & \\
\hline
\end{tabular}

Source: Authors' own research, 2021.

The determined factors coincide with traditional quadratic typology of intrinsic motivation sources of employees in this case as well. According to the rotated component matrix, it is also possible to rank the priority of employees' intrinsic motivation sources during COVID-19 as follows:

1. Sense of choice;

2. Sense of progress;

3. Sense of meaningfulness and

4. Sense of competence.

This ranking together with the reliability as a result of an internal consistency of items by Cronbach's alpha is shown in Table 8.

Table 8. Intrinsic motivation sources-during COVID-19.

\begin{tabular}{ccccc}
\hline \multirow{2}{*}{ Factors } & F1 & F2 & F3 & F4 \\
\cline { 2 - 5 } & Sense of Choice & $\begin{array}{c}\text { Sense of } \\
\text { Progress }\end{array}$ & $\begin{array}{c}\text { Sense of Mean- } \\
\text { ingfulness }\end{array}$ & $\begin{array}{c}\text { Sense of } \\
\text { Competence }\end{array}$ \\
\hline N of Items & 5 & 5 & 5 & 5 \\
Cronbach's & 0.898 & 0.870 & 0.848 & 0.824 \\
$\begin{array}{c}\text { Alpha } \\
\text { \% of Variance }\end{array}$ & 40.902 & 10.506 & 8.170 & 6.275 \\
\hline
\end{tabular}

Source: Authors' own research, 2021.

Based on the above results, it can be stated that the examination of intrinsic motivation sources of employees in the period before and during COVID-19 has shown a change in the content of individual factors when the original structure of these factors is taken into account. Thus, the components of factors remained equal in both analyzed periods while 
their order changed. Similarly, a change in the perception of the importance of the detected sources of intrinsic motivation was demonstrated (See Table 9).

Table 9. Ranking of intrinsic motivation sources before and during COVID-19.

\begin{tabular}{ccc}
\hline Rank & before COVID-19 & during COVID-19 \\
\hline 1 & sense of choice & sense of choice \\
2 & sense of meaningfulness & sense of progress \\
3 & sense of progress & sense of meaningfulness \\
4 & sense of competence & sense of competence \\
\hline
\end{tabular}

Source: Authors' own research, 2021.

When comparing these two periods, there was a change in the significance of the individual components in all sources of intrinsic motivation sources except one (sense of competence) (See Table 10).

Table 10. Ranking of components of intrinsic motivation sources before and during COVID-19.

\begin{tabular}{|c|c|c|c|c|}
\hline \multirow{2}{*}{$\begin{array}{l}\text { Intrinsic } \\
\text { Motivation } \\
\text { Sources }\end{array}$} & \multirow[b]{2}{*}{ Components of Intrinsic Motivation Sources } & \multicolumn{2}{|c|}{ Rank } & \multirow[b]{2}{*}{ Differences } \\
\hline & & $\begin{array}{c}\text { before } \\
\text { COVID-19 }\end{array}$ & $\begin{array}{l}\text { during } \\
\text { COVID-19 }\end{array}$ & \\
\hline \multirow[t]{5}{*}{$\begin{array}{l}\text { sense of } \\
\text { meaningfulness }\end{array}$} & a non-cynical climate (freedom to care deeply) & 10 & 15 & 5 \\
\hline & $\begin{array}{l}\text { clearly identified passions (insight into what we care } \\
\text { about) }\end{array}$ & 7 & 13 & 6 \\
\hline & $\begin{array}{l}\text { an exciting vision (a vivid picture of what can be } \\
\text { accomplished) }\end{array}$ & 6 & 11 & 5 \\
\hline & $\begin{array}{c}\text { relevant task purposes (connection between our work } \\
\text { and the vision) }\end{array}$ & 8 & 12 & 4 \\
\hline & $\begin{array}{c}\text { whole tasks (responsibility for an identifiable product } \\
\text { or service) }\end{array}$ & 9 & 14 & 5 \\
\hline \multirow[t]{5}{*}{ sense of choice } & delegated authority (the right to make decisions) & 1 & 5 & 4 \\
\hline & trust (confidence in an individual's self-management) & 4 & 3 & -1 \\
\hline & security (no fear of punishment for honest mistakes) & 5 & 4 & -1 \\
\hline & $\begin{array}{l}\text { a clear purpose (understanding what we are trying to } \\
\text { accomplish) }\end{array}$ & 2 & 1 & -1 \\
\hline & information (access to relevant facts and sources) & 3 & 2 & -1 \\
\hline \multirow[t]{5}{*}{$\begin{array}{c}\text { sense of } \\
\text { competence }\end{array}$} & $\begin{array}{l}\text { knowledge (an adequate store of insights from } \\
\text { education and experience) }\end{array}$ & 16 & 16 & 0 \\
\hline & positive feedback (information on what is working) & 18 & 18 & 0 \\
\hline & skill recognition (due credit for our successes) & 20 & 20 & 0 \\
\hline & challenge (demanding tasks that fit our abilities) & 17 & 17 & 0 \\
\hline & $\begin{array}{l}\text { high, non-comparative standards (demanding } \\
\text { standards that don't force rankings) }\end{array}$ & 19 & 19 & 0 \\
\hline \multirow[t]{5}{*}{ sense of progress } & $\begin{array}{l}\text { a collaborative climate (co-workers helping each other } \\
\text { succeed) }\end{array}$ & 14 & 10 & -4 \\
\hline & $\begin{array}{c}\text { milestones (reference points to mark stages of } \\
\text { accomplishment) }\end{array}$ & 12 & 7 & -5 \\
\hline & $\begin{array}{c}\text { celebrations (occasions to share enjoyment of } \\
\text { milestones) }\end{array}$ & 11 & 6 & -5 \\
\hline & $\begin{array}{l}\text { access to customers (interactions with those who use } \\
\text { what we've produced) }\end{array}$ & 13 & 8 & -5 \\
\hline & $\begin{array}{c}\text { measurement of improvement (a way to see if } \\
\text { performance gets better) }\end{array}$ & 15 & 9 & -6 \\
\hline
\end{tabular}

Source: Authors' own research, 2021.

In details, the order between "sense of meaningfulness" and "sense of progress" has been replaced in favor of the second mentioned. The factor "sense of choice" remained 
to be the leading factor and the factor "sense of competence" remained to be the least significant one.

The factor "sense of choice" is composed equally as the other analyzed factor by five components. Their order has radically changed when the prospective "before COVID-19" and "during COVID-19" has been applied. Practically no component has remained in its pre-pandemic place. In the case of the factor "sense of progress", practically only the components "a collaborative climate" and "measurement of improvement" were replaced. Similarly, inside the factor "sense of meaningfulness ", only components "clearly identified passions" and "relevant task purposes" were replaced. However, the internal structure of the factor "sense of competence" has remained stable.

These findings are important for theory and practice where original mechanisms of motivation would be prospectively applied only after a formal framework revision. In such a case, indicated change of internal structure of an intrinsic motivational optimum could cause serious functional malformations in the effectiveness of internal marketing communication. It is because not only the best and the worst factors are important to be considered but also the factor architecture inside the structure. When interpreting the structural shift, the factor "sense of progress" would indicate the lack of interpersonal contact and the need of saturation of social needs according to Maslow [74]. On the other hand, "sense of meaningfulness" declines in its importance because its traditional perception relates to the internally perceived value of employer itself where external stimuli are not present. Thus, it can be stated that intrinsic motivation factors have restructured as it has been originally supposed. However, their restructuration indicates the phenomenon of "extrinsictination" intrinsic factors. This fact reflects the pure nature of humans as social beings. This statement could be prospectively supported by the fact that the internal structure of four analyzed components has changed in favor of the externally oriented intrinsic factors- "delegated authority and the right to make decisions" before COVID-19 vs. "clear purpose and understanding of what the company tries to accomplish" during COVID-19 in case of "sense of choice". When external orientation of the intrinsic factor is stated, the main nature of the intrinsic factor is respected-however, the character of the components can be defined in a wider specter and interactions with external environment. On the other hand, this fact does not deny our original assumption of the structural changes in intrinsic motivation sources as it has been partially indicated by Daniels et al. [43]. The change of order of intrinsic motivation sources has verified the change in social value scales caused by the COVID-19 pandemic stated by Konishi et al. and Steinert [39,40]. Moreover, the concept of Islam has been enriched focusing on wide population as a prospective pillar of job market [41]. Via applying this approach, the main conceptual shortage of Adelowo and Surujlal has been removed [42]. Thus, not only healthcare professionals or employees in the most damaged sectors can be considered as significantly influenced by the contemporary crisis [44-46]. Based on above, we can highlight research results as trendsetting in scope of personal management and internal marketing communication. Once at least the basic findings from this research are incorporated, it can be concluded that internal marketing communication reaches new dimension of its incorporation into managerial practice. Similarly, Tam et al. and Greyling et al. have stated the increasing impact of the phenomenon of social psychology in managerial theory and practice and its concepts $[47,48]$.

\section{Managerial Insights}

So far, the phenomenon of social psychology has been a powerful supporting tool of traditional managerial patterns and mechanisms. Nowadays, its importance rises, and effective internal communication creates a platform for optimizing business models. Stable intrinsic motivation structures have changed in scope of the order of their top factors, while the internal structure of these factors has changed internally. Observed trend indicates the need of effective communication as a stimulus for optimal functioning of intrinsic motivation model of individual employees. In order to move in the right direction, 
companies should take into account the following three factors in their activities in relation to employees: (1) meaning (How not to talk about meaning, but to incorporate it into everyday work and all activities? How to give people space to how to understand the needs of individuals?); (2) potential (How to make the most of people's skills and create a culture where knowledge transfer is an integral part of work? How to prepare for closer coexistence with technologies that will become part of teams?); and (3) perspective (How not to perceive the current situation as a threat, but as an opportunity that will lead to better and faster decision-making? How to maintain the necessary transparency in all this?). However, in the light and shadow of complex managerial implications, it would be respected that findings presented in this paper are useful only on national market where the research has been provided. Due to the pandemic, 2020 was a specific year for all companies across industries. Human resources departments had to deal with new and unexpected tasks, and their role changed in part. Although we are still living in a world full of restrictions and anti-pandemic measures, human resources leaders already have to think about what life in companies will look like after a pandemic. Another prospective barrier is the uniform construction of the statistical sample. Despite the fact that in terms of Gauss normal structure of the sample, it size guarantee the reliability and validity of the research outcomes, presented paper does not take into account intrinsic motivation sources relevant to specific professions respectively categories of employees. Thus, prospective future direction of the research could be conducted to this aspect-i.e., analyzing intrinsic motivation sources of individual categories of employees where mainly so-called helping professions and employees from the sectors harmed by the pandemic (gastronomy, transport, travelling ... ) would be interesting. Prospective future implication of the research lies also in its methodological background, which is not typical to be used in scope of this issue. On the other hand, this research could be a pilot study for research focused on other national markets or polymorphic working collectives when the national point of view is taken into account. Similarly, managerial theory and practice would be significantly enriched by research that would extend actual state of knowledge via analyzing the intrinsic motivation factors and their components not only across markets but also across job positions of employees. Optimal approach to such a job positioning would highlight the interaction with customer and competences in the managerial structures. Thus, the research of intrinsic motivation sources would be considered as complex and suitable to be used for the purposes of sustainable internal marketing communication as one of the newly identified pillars of sustainable competitive advantage in turbulent post-pandemic times and the next employee generation.

\section{Conclusions}

The aim of the paper was to identify changes in intrinsic motivation sources of employees caused by the impact of the COVID-19 pandemic and to discuss prospective modifications in the already formulated patterns of internal marketing communication. The data obtained via own questionnaire research have been analyzed via factor analysis in accordance with contemporary trends in managerial analytics. Research was realized during the first quarter of 2020 and 2021 on the sample of 2000 Slovak citizens older than 15 (basic presumption for the legal working subjectivity according to Slovak law). These were the main presumptions for the research: (1) financial situation of many companies would not allow the continuation of attractive extrinsic motivation programs; (2) pandemic has changed individual value scales in favor of non-material ones; and (3) millennials as a strengthening generation on the job market are characterized by a hedonic life approach and preference for intrinsic motivation sources. The examination of intrinsic motivation sources of employees in the period before and during COVID-19 has shown a change in the content of individual factors when the original structure of these factors is taken into account. Thus, the components of factors remained equal in both analyzed periods while their order changed. Similarly, a change in the perception of the importance of the detected sources of intrinsic motivation was demonstrated. The ranking of intrinsic motivation sources before 
the COVID-19 pandemic was the following: (1) sense of choice; (2) sense of meaningfulness; (3) sense of progress; and (4) sense of competence, the ranking of intrinsic motivation sources during the COVID-19 pandemic was the following: (1) sense of choice; (2) sense of progress; (3) sense of meaningfulness; and (4) sense of competence. The study detected the phenomenon of "extrinsictination" of intrinsic factors, which indicates the need of effective communication as a stimulus for optimal functioning of intrinsic motivation model of individual employees. Thus, it can be stated that the already existing principles and patterns of internal marketing communication should be critically reconsidered and motivation systems should be revised to contribute to optimal performance of the company on the market and its sustainable development.

Author Contributions: Conceptualization, J.M. and L.G.; methodology, L.G. and A.K.D.; software, L.G.; formal analysis, M.N. and A.K.D.; investigation, J.M. and L.G.; resources, L.G.; writing—original draft preparation, J.M.; writing—review and editing, L.G. and M.N.; visualization, M.N.; supervision, L.G. and A.K.D.; project administration, J.M.; funding acquisition, J.M. All authors have read and agreed to the published version of the manuscript.

Funding: This research was funded by project VEGA 1/0064/20: Behaviorism in a socially responsible communication strategy of enterprises.

Institutional Review Board Statement: Not applicable.

Informed Consent Statement: Informed consent was obtained from all subjects involved in the study.

Data Availability Statement: Not applicable.

Conflicts of Interest: The authors declare no conflict of interest.

\section{References}

1. Verma, S.; Gustafsson, A. Investigating the emerging COVID-19 research trends in the field of business and management: A bibliometric analysis approach. J. Bus. Res. 2020, 118, 253-261. [CrossRef] [PubMed]

2. Lopez-Lopez, W.; Salas, G.; Vega-Arce, M.; Cornejo-Araya, C.A.; Barboza-Palomino, M.; Ho, Y.-S. Publications on COVID-19 in high impact factor journals: A bibliometric analysis. Univ. Psychol. 2020, 19. [CrossRef]

3. Casado-Aranda, L.-A.; Sanchez-Fernandez, J.; Viedma-del-Jesus, M. Analysis of the scientific production of the effect of COVID-19 on the environment: A bibliometric study. Environ. Res. 2021, 193, 110416. [CrossRef] [PubMed]

4. Hitka, M.; Starchon, P.; Caha, Z.; Lorincova, s.; Sedliacikova, M. The global health pandemic and its impact on the motivation of employees in micro and small enterprises: A case study in the Slovak Republic. Econ. Res. Ekon. Istraz. 2021. [CrossRef]

5. Parameswar, N.; Chaubey, A.; Dhir, S. Black swan: Bibliometric analysis and development of research agenda. Benchmarking 2021. ahead-of-print. [CrossRef]

6. Bressan, A.; Alonso, A.D.; Kok, S.K. Confronting the unprecedented: Micro and small businesses in the age of coronavirus disease 2019. Int. J. Entrep. Behav. Res. 2021, 27, 799-820. [CrossRef]

7. Hsieh, H.-C.; Nguyen, X.-H.; Wang, T.-C.; Lee, J.-Y. Prediction of knowledge management for success of franchise hospitality in a post-pandemic economy. Sustainability 2020, 12, 8755. [CrossRef]

8. Ansell, C.; Boin, A. Taming deep uncertainty: The potential of pragmatist principles for understanding and improving strategic crisis management. Adm. Soc. 2019, 51, 1079-1112. [CrossRef]

9. Castles, F.G. Black swans and elephants on the move: The impact of emergencies on the welfare state. J. Eur. Soc. Policy 2010, 20, 91-101. [CrossRef]

10. Haggard, K.S.; Jones, J.S.; Witte, H.D. Black Cats or Black Swans? Outliers, Seasonality in Return Distribution Properties, and the Halloween Effect. Manag. Financ. 2015, 41, 642-657. [CrossRef]

11. Anholon, R.; Silva, D.; Pinto, J.S.; Rampasso, I.S.; Domingos, M.L.C.; Dias, J.H.O. COVID-19 and the administrative concepts neglected: Reflections for leaders to enhance organizational development. Kybernetes 2021, 50, 1654-1660. [CrossRef]

12. Rind, E.; Kimpel, K.; Preiser, C.; Papenfuss, F.; Wagner, A.; Alsyte, K.; Siegel, A.; Klink, A.; Steinhilber, B.; Kauderer, J.; et al. Adjusting working conditions and evaluating the risk of infection during the COVID-19 pandemic in different workplace settings in Germany: A study protocol for an explorative modular mixed methods approach. BMJ Open 2020, 10, e043908. [CrossRef]

13. Bhattacharyya, S.S.; Thakre, S. Coronavirus pandemic and economic lockdown; study of strategic initiatives and tactical responses of firms. Int. J. Organ. Anal. 2021. ahead-of-print. [CrossRef]

14. Ebersberger, B.; Kuckertz, A. Hop to it! The impact of organization type on innovation response time to the COVID-19 crisis. J. Bus. Res. 2021, 124, 126-135. [CrossRef]

15. Jankelova, N.; Misun, J. Key competencies of agricultural managers in the acute stage of the COVID-19 crisis. Agriculture 2021, 11, 59. [CrossRef] 
16. Lawler, E.E.; Porter, L.W.; Tennenbaum, A. Managers' attitudes toward interaction episodes. J. Appl. Psychol. 1968, 52, 432-439. [CrossRef]

17. Amabile, T.M.; Kramer, S.J. The power of small wins. Harv. Bus. Rev. 2011, 89, 70-80.

18. Cerasoli, C.P.; Nicklin, J.M.; Ford, M.T. Intrinsic motivation and extrinsic incentives jointly predict performance: A 40-year meta-analysis. Psychol. Bull. 2014, 140, 980-1008. [CrossRef]

19. Ryan, R.M.; Deci, E.L. Intrinsic and extrinsic motivations: Classic definitions and new directions. Contemp. Educ. Psychol. 2000, 25, 54-67. [CrossRef] [PubMed]

20. Derfler-Rozin, R.; Pitesa, M. Motivation purity bias: Expression of extrinsic motivation undermines perceived intrinsic motivation and engenders bias in selection decisions. Acad. Manag. J. 2020, 63, 1840-1864. [CrossRef]

21. Bastari, A.; Eliyana, A.; Syabarrudin, A.; Arief, Z.; Emur, A.P. Digitalization in banking sector: The role of intrinsic motivation. Heliyon 2020, 6, e05801. [CrossRef]

22. Malek, S.L.; Sarin, S.; Haon, C. Extrinsic rewards, intrinsic motivation, and new product development performance. J. Prod. Innov. Manag. 2020, 37, 528-551. [CrossRef]

23. Olah, J.; Sadaf, R.; Mate, D.; Popp, J. The influence of the management success factors of logistics service providers on firms' competitiveness. Pol. J. Manag. Stud. 2018, 17, 175-193. [CrossRef]

24. Mardanov, I. Intrinsic and extrinsic motivation, organizational context, employee contentment, job satisfaction, performance and intention to stay. Evid. Based HRM Glob. Forum Empir. Scholarsh. 2020, 9, 223-240. [CrossRef]

25. Montani, F.; Courcy, F.; Battistelli, A.; de Witte, H. Job insecurity and innovative work behaviour: A moderated mediation model of intrinsic motivation and trait mindfulness. Stress Health 2021. [CrossRef]

26. Cabanas, S.; Proenca, T.; Carozzo-Todaro, M. Pay for individual performance: Aiding or harming sustainable intrinsic motivation? Sustainability 2020, 12, 6322. [CrossRef]

27. Moon, T.-W.; Youn, N.; Hur, W.-M.; Kim, K.-M. Does employees' spirituality enhance job performance? The mediating roles of intrinsic motivation and job crafting. Curr. Psychol. 2020, 39, 1618-1634. [CrossRef]

28. Saether, E.A. Creativity-contingent rewards, intrinsic motivation, and creativity: The importance of fair reward evaluation procedures. Front. Psychol. 2020, 11, 974. [CrossRef] [PubMed]

29. Shafi, M.; Lei, Z.; Song, X.; Sarker, M.N.I. The effects of transformational leadership on employee creativity: Moderating role of intrinsic motivation. Asia Pac. Manag. Rev. 2020, 25, 166-176. [CrossRef]

30. Su, W.; Lyu, B.; Chen, H.; Zhang, Y. How does servant leadership influence employees' service innovative behavior? The roles of intrinsic motivation and identification with the leader. Balt. J. Manag. 2020, 15, 571-586. [CrossRef]

31. Terjesen, S. Entrepreneurial finance: Research, practice, and policy for post-Covid-19 economic recovery. J. Risk Financ. Manag. 2021, 14, 18. [CrossRef]

32. Ellul, A.; Erel, I.; Rajan, U. The COVID-19 pandemic crisis and corporate finance. Rev. Corp. Financ. Stud. 2020, 9, 421-429. [CrossRef]

33. Acharya, V.V.; Steffen, S. The risk of being a fallen angel and the corporate dash for cash in the midst of COVID. Rev. Corp. Financ. Stud. 2020, 9, 430-471. [CrossRef]

34. Carletti, E.; Oliviero, T.; Pagano, M.; Pelizzon, L.; Subrahmanyam, M.G. The COVID-19 shock and equity shortfall: Firm-level evidence from Italy. Rev. Corp. Financ. Stud. 2020, 9, 534-568. [CrossRef]

35. Ramelli, S.; Wagner, A.F. Feverish stock price reactions to COVID-19. Rev. Corp. Financ. Stud. 2020, 9, 622-655. [CrossRef]

36. Chang, C.-L.; McAleer, M.; Wong, W.-K. Risk and financial management of COVID-19 in business, economics and finance. J. Risk Financ. Manag. 2020, 13, 102. [CrossRef]

37. Achou, B.; Boisclair, D.; D'Astous, P.; Fonseca, R.; Glenzer, F.; Michaud, P.-C. Early impact of the COVID-19 pandemic on household finances in Quebec. Can. Public Policy Anal. De Polit. 2020, 46, S217-S235. [CrossRef]

38. Spatt, C.S. A tale of two crises: The 2008 mortgage meltdown and the 2020 COVID-19 crisis. Rev. Asset Pricing Stud. 2020, 10, 759-790. [CrossRef]

39. Konishi, Y.; Saito, T.; Ishikawa, T.; Kanai, H.; Igei, N. How did japan cope with COVID-19? Big data and purchasing behavior. Asian Econ. Pap. 2021, 20, 35-59. [CrossRef]

40. Steinert, S. Corona and value change. The role of social media and emotional contagion. Ethics Inf. Technol. 2020, 1-10. [CrossRef]

41. Islam, T.; Pitafi, A.H.; Arya, V.; Wang, Y.; Akhtar, N.; Mubarik, S.; Xiaobei, L. Panic buying in the COVID-19 pandemic: A multi-country examination. J. Retail. Consum. Serv. 2020, 59, 102357. [CrossRef]

42. Adelowo, C.M.; Surujlal, J. Academic entrepreneurship and traditional academic performance at universities: Evidence from a developing country. Pol. J. Manag. Stud. 2020, 22, 9-25. [CrossRef]

43. Daniels, L.M.; Goegan, L.D.; Parker, P.C. The impact of COVID-19 triggered changes to instruction and assessment on university students' self-reported motivation, engagement and perceptions. Soc. Psychol. Educ. 2021, 24, 299-318. [CrossRef]

44. Sakib, N.; Akter, T.; Zohra, F.; Bhuiyan, A.K.M.I.; Mamun, M.A.; Griffiths, M.D. Fear of COVID-19 and depression: A comparative study among the general population and healthcare professionals during COVID-19 pandemic crisis in bangladesh. Int. J. Ment. Health Addict. 2021, 1-17. [CrossRef]

45. Ellison, B.; McFadden, B.; Rickard, B.J.; Wilson, N.L.W. Examining food purchase behavior and food values during the COVID-19 pandemic JEL codes. Appl. Econ. Perspect. Policy 2021, 43, 58-72. [CrossRef] 
46. Zheng, D.; Luo, Q.; Ritchie, B.W. Afraid to travel after COVID-19? Self-protection, coping and resilience against pandemic 'Travel fear'. Tour. Manag. 2021, 83, 104261. [CrossRef]

47. Tam, K.-P.; Leung, A.K.-y.; Khan, S. The new normal of social psychology in the face of the COVID-19 pandemic: Insights and advice from leaders in the field. Asian J. Soc. Psychol. 2021, 24, 8-9. [CrossRef]

48. Greyling, T.; Rossouw, S.; Adhikari, T. A tale of three countries: What is the relationship between COVID-19, lockdown and happiness? S. Afr. J. Econ. 2021, 89, 25-43. [CrossRef] [PubMed]

49. International Labour Organization. Youth \& COVID-19: Impacts on jobs, education, rights and mental well-being. Available online: https://www.ilo.org/wcmsp5/groups/public/---ed_emp/documents/publication/wcms_753026.pdf (accessed on 1 April 2021).

50. Cennamo, L.; Gardner, D. Generational differences in work values, outcomes and person-organisation values fit. J. Manag. Psychol. 2008, 23, 891-906. [CrossRef]

51. Misamer, M.; Thies, B. Establishing a culture of trust between leaders and their employees measures to promote commitment and participation (Especially considering the millenials). Gio-Gr. Interakt. Organ. Z. Fuer Angew. Organ. 2017, 48, 225-233. [CrossRef]

52. Tan, K.-L.; Lew, T.-Y.; Sim, A.K.S. Effect of work engagement on meaningful work and psychological capital: Perspectives from social workers in New Zealand. Empl. Relat. 2020, 43, 807-826. [CrossRef]

53. Smaliukiene, R.; Bekesiene, S. Towards sustainable human resources: How generational differences impact subjective wellbeing in the military? Sustainability 2020, 12, 10016. [CrossRef]

54. Shi, Y.; Xie, J.; Zhou, Z.E.; Tang, H.; Ma, H.; Zhang, H.; Zhang, N. Family-supportive supervisor behaviors and employees' life satisfaction: The roles of work-self facilitation and generational differences. Int. J. Stress Manag. 2020, 27, 262-272. [CrossRef]

55. Ali, M.; Arbi, K.A.; Raza, B.; Malik, S.Z.; Sheikh, L. Does managerial coachingeffect subordinates' feedback orientation? Mediating role of affective supervisory commitment. Pol. J. Manag. Stud. 2020, 22, 9-21. [CrossRef]

56. Mahmoud, A.B.; Fuxman, L.; Mohr, I.; Reisel, W.D.; Grigoriou, N. “We aren't your reincarnation!” workplace motivation across X, $\mathrm{Y}$ and $\mathrm{Z}$ generations. Int. J. Manpow. 2020. [CrossRef]

57. Hashiguchi, N.; Sengoku, S.; Kubota, Y.; Kitahara, S.; Lim, Y.; Kodama, K. Age-dependent influence of intrinsic and extrinsic motivations on construction worker performance. Int. J. Environ. Res. Public Health 2021, 18, 111. [CrossRef]

58. Brink, K.E.; Zondag, M.M. Examining job attribute preferences across three generational cohorts. J. Career Dev. $2021,48,60-72$. [CrossRef]

59. Tuncbilek, M.M.; Sucu, U. Job satisfaction and work stress in the context of generation X and Y: A study on participation banks. Int. J. Contemp. Econ. Adm. Sci. 2020, 10, 378-414. [CrossRef]

60. Gurbuz, S.; Aytekin, I. Are work attitudes of generations myth or real? Evidence from the United States and Turkey. Istanb. Bus. Res. 2020, 49, 249-271. [CrossRef]

61. Lizbetinova, L. The quality of communication in the context of regional development. Deturope Cent. Eur. J. Reg. Dev. Tour. 2014, 6, 22-38.

62. Hitka, M.; Rozsa, Z.; Potkany, M.; Lizbetinova, L. Factors forming employee motivation influenced by regional and age-related differences. J. Bus. Econ. Manag. 2019, 20, 674-693. [CrossRef]

63. Hitka, M.; Lorincova, S.; Potkany, M.; Balazova, Z.; Caha, Z. Differentiated approach to employee motivation in terms of finance. J. Bus. Econ. Manag. 2021, 22, 118-134. [CrossRef]

64. Koisova, E.; Masarova, J.; Habanik, J. Regional differences in the labour market in Slovakia and the Czech Republic. J. Compet. 2018, 10, 104-117. [CrossRef]

65. Jankalova, M.; Vartiak, L. Identification of bases for evaluation of the business excellence status in relation to the Csr concept. Int. J. Qual. Res. 2017, 11, 315-330. [CrossRef]

66. Kwak, S.G.; Kim, J.H. Central limit theorem: The cornerstone of modern statistics. Korean J. Anesthesiol. 2017, 70, 144. [CrossRef]

67. Klepek, M.; Matusinska, K. Emerging Socio-Demographic Group of Singles in Selected EU Countries and Its Consequences for Business Environment. In Innovation Management and Sustainable Economic Competitive Advantage: From Regional Development to Global Growth; Soliman, V.K.S., Ed.; Int Business Information Management Assoc-Ibima: Madrid, Spain, 2015; Volume I-VI, pp. 163-170.

68. Valaskova, M.; Krizanova, A. The passenger satisfaction survey in the regional integrated public transport system. Promet Traffic Transp. 2008, 20, 401-404.

69. Lizbetinova, L.; Starchon, P.; Lorincova, S.; Weberova, D.; Prusa, P. Application of cluster analysis in marketing communications in small and medium-sized enterprises: An empirical study in the Slovak Republic. Sustainability 2019, 11, 2302. [CrossRef]

70. Parobek, J.; Palus, H.; Kalamarova, M.; Loucanova, E.; Supin, M.; Krizanova, A.; Stofkova, K.R. Energy utilization of renewable resources in the European Union-cluster analysis approach. Bioresources 2016, 11, 984-995. [CrossRef]

71. Palus, H.; Mat'ova, H.; Krizanova, A.; Parobek, J. A survey of awareness of forest certification schemes labels on wood and paper products. Acta Fac. Xylologiae Zvolen 2014, 56, 129-138.

72. Munro, B.H. Statistical Methods for Health Care Research, 5th ed.; Lippincott Williams \& Wilkins: Philadelphia, PA, USA, 2005.

73. Bracinikova, V.; Matusinska, K. Clustering of millennials by brand perceptions in relation to demographic factors. Cent. Eur. Bus. Rev. 2020, 9, 63-80. [CrossRef]

74. Vrtana, D.; Krizanova, A.; Skorvagova, E.; Valaskova, K. Exploring the affective level in adolescents in relation to advertising with a selected emotional appeal. Sustainability 2020, 12, 8287. [CrossRef] 